\title{
THE EFFECT OF STORAGE IN CONTROLLED ATMOSPHERE ON THE QUALITY AND HEALTH-PROMOTING COMPONENTS OF BROCCOLI (BRASSICA OLERACEA VAR. ITALICA)
}

\author{
Ewa BADEŁEK, Ryszard KOSSON, Franciszek ADAMICKI \\ Research Institute of Horticulture \\ Konstytucji 3 Maja 1/3, 96-100 Skierniewice, Poland \\ Received: December 13, 2012; Accepted: January 7, 2013
}

\begin{abstract}
Summary
The aim of the study was to determine the effect of storage conditions on the quality and health-promoting components of broccoli. Broccoli heads cv. Marathon $\mathrm{F}_{1}$ were stored at $0^{\circ} \mathrm{C}$ for 100 days in controlled atmospheres containing: 1) $15 \% \mathrm{CO}_{2}-3 \% \mathrm{O}_{2}$, 2) $10 \% \mathrm{CO}_{2}-3 \% \mathrm{O}_{2}$, 3) $8 \% \mathrm{CO}_{2}-1 \% \mathrm{O}_{2}$, 4) $5 \% \mathrm{CO}_{2}$ $-3 \% \mathrm{O}_{2}$. In the control treatment, broccoli heads were stored in normal atmosphere in crates lined with PE film. Before and after storage, chemical analyses were performed for the content of ascorbic acid, total sugars and glucosinolates - sulforaphane and indole-3-carbinol. Additionally, after storage the quality of broccoli heads was assessed visually on a 1-10 point scale, and the percentage of marketable heads was determined. The total content of sulforaphane and indole-3-carbinol in fresh broccoli was lower in comparison with stored broccoli. The sulforaphane content in fresh broccoli was about twice as high as that of indole-3-carbinol. Storage in an atmosphere consisting of $5 \% \mathrm{CO}_{2}-3 \% \mathrm{O}_{2}$ was more favourable in comparison with the other gas concentrations in terms of glucosinolate content. A decrease in the content of ascorbic acid and total sugars during storage was noted in all the treatments. The highest loss of these components occurred in broccoli stored in an atmosphere consisting of $15 \%$ $\mathrm{CO}_{2}$ and $3 \% \mathrm{O}_{2}$. Broccoli heads stored in normal atmosphere completely lost their market quality due to decay, but the quality of broccoli kept in CA was satisfactory.
\end{abstract}

key words: broccoli, storage, controlled atmosphere, glucosinolates, sulforaphane, indole-3-carbinol

\section{INTRODUCTION}

Brassica vegetables are a rich source of many components that are valuable for human health, such as glucosinolates, flavonoids, carotenoids, vitamins $\mathrm{C}$ and $\mathrm{E}$, macro- and microelements (potassium, calcium, magnesium, iron, sulfur). Epidemiological studies have shown that 
a diet rich in brassica vegetables reduces the risk of cancer of lung, stomach, colon and other organs. The antitumour action of brassica vegetables is associated with high levels of glucosinolates. Damage to Brassica plant tissue results in the release of the enzyme myrosinase, which causes the hydrolysis of glucosinolates to isothio-cyanates, indoles, nitriles, and others. The anticancer activity is attributed to the isothiocyanates and indoles (Van Poppel et al. 1999). In the mechanism of the antitumor action of isothiocyanates the main role plays the activating enzymes responsible for the removal of toxic substances that may produce cancer-causing changes in the human body (Zhang et al. 1992, Fahey \& Talalay 1999, Fahey \& Stephenson 1999).

The most important factor affecting the level of glucosinolates in the plant is the genotype (Farnham et al. 2005, Charron et al. 2005, O'Hare et al. 2007). The content of glucosinolates is also dependent on the cultivar (Rosa \& Rodrigues 2001, Horbowicz \& Babik 2005a, Sosińska \& Obiedziński 2007, Jagdish et al. 2007, Cartea et al. 2008), harvest date (Rosa \& Rodriguez 2001, Charron et al. 2005), fertilization (Horbowicz \& Babik 2005b), the part of the plant, as well as the development phase. Brown et al. (2003) found higher glucosinolate levels in resting and germinating seeds of Arabidopsis thaliana as compared with the levels in the flowers, fruits, leaves and roots. Higher content of glucosinolates were also found in broccoli florets than in the leaves (Liang et al. 2006) and the stem (Sosińska \& Obiedziński 2007).
The highest glucosinolate content was observed in 3-day-old broccoli seedlings (Zhang et al. 1992, Fahey et al. 1997, Bellostas et al. 2007, Rosa et al. 2007). The levels of glucosinolates are also modified by environmental conditions (Ciska et al. 2000, Farnham et al. 2004, Aires et al. 2006, Horbowicz \& Babik 2005a, Rosa et al. 2007, Jones et al. 2007). Schonhof et al. (2007) also reported a higher glucosinolate content in broccoli heads grown in a greenhouse where the level of carbon dioxide was raised to $685-820 \mu \mathrm{l} \cdot \mathrm{L}^{-1}$, in comparison with atmospheric air containing 430-480 $\mu \mathrm{l} \cdot \mathrm{L}^{-1}$ carbon dioxide.

By analyzing the content of glucosinolates in 7-day-old seedlings of 21 species of plants belonging to the Brassica family, it was found that broccoli had the highest anticancer potential because of the content and profile of glucosinolates (O'Hare et al. 2007). More than a dozen glucosinolates have been identified in broccoli, the largest amounts of which are those of glucoraphanin $\left(7.1 \mu \mathrm{mol} \cdot \mathrm{g}^{-1}\right.$ DW), glucobrassicin $\left(1.1 \mu \mathrm{mol} \cdot \mathrm{g}^{-1}\right.$ DW), gluconapin $\left(1.0 \mu \mathrm{mol} \cdot \mathrm{g}^{-1} \mathrm{DW}\right)$ and progoitrin $\left(1.0 \mu \mathrm{mol} \cdot \mathrm{g}^{-1} \quad \mathrm{DW}\right)$ (Kushad et al. 1999). The most bioactive products of glucosinolate hydrolysis are: sulforaphane (derived from glucoraphanin), allyl isothiocyanate (derived from sinigrin), and indole-3carbinol (derived from glucobrassicin) (Jones et al. 2006). The antioxidant and anticarcinogenic properties of sulforaphane were discovered in 1992 by Zhang et al., who isolated it from mature broccoli florets (Zhang et al. 1992). Natural sulforaphane is mainly derived from the seeds of broccoli 
(Liang et al. 2007). Indole-3-carbinol also has antioxidant and anticarcinogenic properties, particularly in reducing the risk of breast and cervical cancers (Bradlow et al. 1999).

The glucosinolate content in brassica vegetables is also affected by post-harvest treatment and storage conditions. Broccoli is among the vegetables that are particularly perishable when stored because they are characterized by a high respiration rate and rapid loss of water. When stored under inappropriate conditions, freshly harvested heads rapidly lose their marketable value. In particular, there occurs a change in colour from green to yellow, wilting of the florets and opening of the buds. Immediately after harvesting, the heads must be instantly chilled to a low temperature. Storage of broccoli for 24 hours at $+20^{\circ} \mathrm{C}$ before cooling results in a deterioration in quality, shortening of the storage period, and a significant reduction in glucoraphanin content (Chao-Jiong et al. 2006).

The optimal conditions for storing broccoli are a temperature of $0^{\circ} \mathrm{C}$ and a high relative humidity of 95 $98 \%$. The storage life of broccoli heads can be extended by using various types of packaging, and also by storing them in a controlled atmosphere (Adamicki 2002). The gas composition of the atmosphere has a great influence on the colour of the florets, especially when broccoli heads are stored at a higher temperature. The colour is one of the most important factor of the quality of the heads. Broccoli heads are better at retaining the green colour when they are stored at low concentrations of oxygen in combination with high concentrations of carbon dioxide (Schouten et al. 2009). In a study by Hansen et al. (1995), the beginning of yellowing was observed on day 7 of storing broccoli in normal atmosphere at $+10^{\circ} \mathrm{C}$, whereas when broccoli was stored at the same temperature but in a controlled atmosphere containing $0.5 \%$ $\mathrm{O}_{2}, 0.5 \% \mathrm{O}_{2}+20 \% \mathrm{CO}_{2}$, or $20 \% \mathrm{CO}_{2}$ the broccoli heads were still green. The optimal conditions that allow the heads to preserve good quality and extend the storage period also positively affect the levels of glucosinolates (Rangkadilok et al. 2002) and phytosterols (Gajewski et al. 2011).

The aim of this study was to determine the effect of storage conditions on the quality of broccoli heads and the amounts of health-promoting components in them.

\section{MATERIALS AND METHODS}

The experiment with the storage of broccoli cv. Marathon $\mathrm{F}_{1}$ was conducted in the years 2008-2011. The broccoli plants were grown in an experimental field of the Institute of Horticulture in accordance with agrotechnical recommendations. After harvesting, the broccoli heads were placed for several hours in a cooling chamber at $0^{\circ} \mathrm{C}+1^{\circ} \mathrm{C}$ for pre-cooling. Next, the heads were arranged in plastic crates and placed in gas-tight containers in the cooling chamber at a temperature of $0^{\circ} \mathrm{C}$ and relative humidity of about $80 \%$. The following gas composition of the atmosphere was maintained in the containers: 1) $\left.15 \% \mathrm{CO}_{2}-3 \% \mathrm{O}_{2}, 2\right) 10 \% \mathrm{CO}_{2}-$ $\left.\left.3 \% \mathrm{O}_{2}, 3\right) 8 \% \mathrm{CO}_{2}-1 \% \mathrm{O}_{2}, 4\right) 5 \%$ 
$\mathrm{CO}_{2}-3 \% \mathrm{O}_{2}$. The control treatment consisted of broccoli heads stored in the same chamber in normal atmosphere, in crates lined with polyethylene film with free access of atmospheric air. Each treatment consisted of 4 replicates of 10 heads each. The gas composition of the atmosphere and maintenance of that composition at an appropriate level were monitored and automatically controlled by an Oxystat 200 controller (David Bishop Inst.). The broccoli heads were stored for 100 days. Immediately after harvest, the heads were chemically analyzed for ascorbic acid content by Tillman's method (according to PN90A-75101/07), total sugars by the Luff-Schoorl method, and glucosinolates - sulforaphane and indole-3carbinol according to Liang et al. (2006). The colour of the heads was also measured with a MiniScan XE Plus colorimeter. After storage, chemical analyses were performed again for the components mentioned above, and the percentage of marketable heads was determined. A visual assessment of the quality of the heads was also carried out according to own ranking scale:

marketable value: 10 - excellent (heads look as if freshly harvested), 9 - very good, 8 - good, 7 - quite good, 6 - satisfactory, 5 - mediocre (heads unsuitable for market), 4 - poor, 3 defective, 2 - bad, 1 - very bad;

compactness of florets: 10 - very compact, 9 - compact, 8 - hardly any loss of compactness, 7 - a slight loss of compactness, 6 - visible loss of compactness, 5 - definite loss of compactness, 4 - loose, 3 - very loose, 2 - scattered, 1 - strongly scattered; decay: 10 - no decay, 9 - 1 small spot, 8 - 2 small spots, 7 - 3 small spots, 6 - slight decay, 5 - medium degree of decay, markedly reducing the quality, 4 - quite severe decay, 3 - severe decay, 2 - very severe decay, 1 - completely rotten.

The results were analyzed with univariate variance analysis, and the mean values were compared with the Newman-Keuls test at a significance level of $\mathrm{P}=0.05$.

\section{RESULTS AND DISCUSSION}

After 100 days of storage in normal atmosphere (control), in all the storage seasons there was a very low percentage of marketable broccoli heads because of very severe decay of the heads. In all the years of the experiment, the percentage share of marketable heads was significantly lower in the atmosphere containing $5 \% \mathrm{CO}_{2}$ and $3 \% \mathrm{O}_{2}$ than in the other controlled atmosphere treatments. A higher percentage share of marketable heads was recorded in the treatments with a higher concentration of carbon dioxide. The highest percentage share of marketable heads was recorded in the treatments containing 10 and $15 \%$ carbon dioxide, although the differences were not statistically significant (Table 1).

The marketable value of the broccoli heads stored in an atmosphere with a higher concentration of carbon dioxide - 8, 10 and 15\% - was satisfactory to quite good. In those treatments there was no decay of the florets, or only small changes found on single buds, and only a slight loss of compactness in comparison with 
fresh heads. The marketable value of the broccoli heads stored in the atmosphere containing $5 \% \quad \mathrm{CO}_{2}-3 \%$ $\mathrm{O}_{2}$ was in two storage seasons lower compared with the other treatments of controlled atmosphere. In that treatment, during 2008/9 and 2010/11 storage seasons the decay of broccoli heads occurred at a medium level, which resulted in a significant deterioration in their quality. There were no major differences, however, in the compactness of the heads as com- pared with the heads stored at the other treatments of oxygen and carbon dioxide (Tables 2, 3).

In this study, fresh broccoli heads in different seasons were characterized by a varying degree of yellowness and greenness (Table 6). In the first two storage seasons there was no effect of the different gas compositions of the atmosphere on the changes in the colour indices of the broccoli heads.

Table 1. Percentage of marketable broccoli heads after 100 days of storage

\begin{tabular}{lccc}
\hline \multirow{2}{*}{ Treatment } & \multicolumn{3}{c}{ Storage season } \\
\cline { 2 - 4 } & $2008 / 2009$ & $2009 / 2010$ & $2010 / 2011$ \\
\hline Control (air) & $0 \mathrm{a}$ & $7.5 \mathrm{a}$ & $5.0 \mathrm{a}$ \\
\hline $5 \% \mathrm{CO}_{2}-3 \% \mathrm{O}_{2}$ & $27.5 \mathrm{~b}$ & $67.5 \mathrm{~b}$ & $32.5 \mathrm{~b}$ \\
\hline $8 \% \mathrm{CO}_{2}-1 \% \mathrm{O}_{2}$ & $82.5 \mathrm{c}$ & $77.5 \mathrm{~b}$ & $90.0 \mathrm{c}$ \\
\hline $10 \% \mathrm{CO}_{2}-3 \% \mathrm{O}_{2}$ & $97.5 \mathrm{c}$ & $75.0 \mathrm{~b}$ & $100.0 \mathrm{c}$ \\
\hline $15 \% \mathrm{CO}_{2}-3 \% \mathrm{O}_{2}$ & $95.0 \mathrm{c}$ & $87.5 \mathrm{~b}$ & $100.0 \mathrm{c}$ \\
\hline
\end{tabular}

Means in columns followed by the same letter do not differ significantly at $\mathrm{p}=0.05$.

Table 2. Marketable value and rotting of broccoli heads after 100 days of storage

\begin{tabular}{lcccccc}
\hline & \multicolumn{5}{c}{ Marketable value } \\
\cline { 2 - 7 } \multicolumn{1}{c}{ Treatment } & \multicolumn{5}{c}{ Storage season } \\
\cline { 2 - 7 } & $2008 /$ & $2009 /$ & $2010 /$ & $2008 /$ & $2009 /$ & $2010 /$ \\
& 2009 & 2010 & 2011 & 2009 & 2010 & 2011 \\
\hline Control (air) & $1.6 \mathrm{a}$ & $4.2 \mathrm{a}$ & $1.7 \mathrm{a}$ & $1.7 \mathrm{a}$ & $4.9 \mathrm{a}$ & $1.9 \mathrm{a}$ \\
\hline $5 \% \mathrm{CO}_{2}-3 \% \mathrm{O}_{2}$ & $4.4 \mathrm{~b}$ & $6.6 \mathrm{~b}$ & $4.5 \mathrm{~b}$ & $5.6 \mathrm{~b}$ & $7.9 \mathrm{~b}$ & $5.3 \mathrm{~b}$ \\
\hline $8 \% \mathrm{CO}_{2}-1 \% \mathrm{O}_{2}$ & $6.2 \mathrm{c}$ & $6.5 \mathrm{~b}$ & $6.7 \mathrm{c}$ & $8.8 \mathrm{c}$ & $8.3 \mathrm{~b}$ & $9.1 \mathrm{c}$ \\
\hline $10 \% \mathrm{CO}_{2}-3 \% \mathrm{O}_{2}$ & $6.6 \mathrm{c}$ & $6.3 \mathrm{~b}$ & $7.6 \mathrm{~d}$ & $9.3 \mathrm{c}$ & $7.3 \mathrm{~b}$ & $9.7 \mathrm{c}$ \\
\hline $15 \% \mathrm{CO}_{2}-3 \% \mathrm{O}_{2}$ & $6.4 \mathrm{c}$ & $6.9 \mathrm{~b}$ & $7.4 \mathrm{~d}$ & $9.8 \mathrm{c}$ & $8.4 \mathrm{~b}$ & $10.0 \mathrm{c}$ \\
\hline
\end{tabular}

Note: see Table 1 
Table 3. Compactness of broccoli heads after 100 days of storage

\begin{tabular}{lccc}
\hline \multirow{2}{*}{ Treatment } & \multicolumn{3}{c}{ Storage season } \\
\cline { 2 - 4 } & $2008 / 2009$ & $2009 / 2010$ & $2010 / 2011$ \\
\hline Fresh broccoli (before storage) & 10 & 10 & 10 \\
\hline $5 \% \mathrm{CO}_{2}-3 \% \mathrm{O}_{2}$ & $6.8 \mathrm{a}$ & $8.5 \mathrm{a}$ & $7.5 \mathrm{a}$ \\
\hline $8 \% \mathrm{CO}_{2}-1 \% \mathrm{O}_{2}$ & $7.3 \mathrm{~b}$ & $7.9 \mathrm{a}$ & $7.4 \mathrm{a}$ \\
\hline $10 \% \mathrm{CO}_{2}-3 \% \mathrm{O}_{2}$ & $7.8 \mathrm{c}$ & $8.4 \mathrm{a}$ & $7.8 \mathrm{a}$ \\
\hline $15 \% \mathrm{CO}_{2}-3 \% \mathrm{O}_{2}$ & $7.5 \mathrm{~b}$ & $8.3 \mathrm{a}$ & $8.0 \mathrm{a}$ \\
\hline
\end{tabular}

Note: see Table 1

The total sugar content was highest in fresh broccoli heads. During storage, the sugar content decreased in all the treatments. The decrease was greater the higher the carbon dioxide content in the atmosphere. The lowest total sugar content was found after storage in the atmospheres containing 10 and $15 \%$ carbon dioxide (Table 4 ). In two years of the study, the ascorbic acid content was higher in fresh broccoli heads than in the stored ones. In the 2009/2010 and 2010/2011 storage seasons there was a decrease in ascorbic acid content, the decrease being particularly large in the atmospheres containing 10 and $15 \%$ carbon dioxide. In the 2008/2009 storage season, a decrease in the ascorbic acid content occurred in the atmospheres containing 10 and $15 \%$ carbon dioxide, but in the atmospheres containing 5\% carbon dioxide and $3 \%$ oxygen, and $8 \%$ carbon dioxide and $1 \%$ oxygen there was a slight increase in ascorbic acid content during storage. The highest content of ascorbic acid and sugars were recorded after storage in the atmosphere containing $8 \%$ carbon dioxide and $1 \%$ oxygen (Table 4 ).

Table 4. Contents of vitamin $\mathrm{C}$ and sugars in fresh broccoli and after 100 days of storage

\begin{tabular}{|c|c|c|c|c|c|c|}
\hline \multirow{4}{*}{ Treatment } & \multicolumn{3}{|c|}{$\begin{array}{c}\text { Vitamin C } \\
\left(\mathrm{mg} 100 \mathrm{~g}^{-1} \mathrm{FW}\right)\end{array}$} & \multicolumn{3}{|c|}{$\begin{array}{l}\text { Total sugars } \\
(\% \mathrm{FW})\end{array}$} \\
\hline & \multicolumn{6}{|c|}{ Storage season } \\
\hline & $2008 /$ & $2009 /$ & $2010 /$ & $2008 /$ & $2009 /$ & $2010 /$ \\
\hline & 2009 & 2010 & 2011 & 2009 & 2010 & 2011 \\
\hline $\begin{array}{l}\text { Fresh broccoli (before } \\
\text { storage) }\end{array}$ & $97.90 \mathrm{c}$ & $93.66 \mathrm{e}$ & $90.81 \mathrm{e}$ & $2.73 \mathrm{~d}$ & $3.29 \mathrm{~d}$ & $2.45 \mathrm{~d}$ \\
\hline $5 \% \mathrm{CO}_{2}-3 \% \mathrm{O}_{2}$ & $100.95 \mathrm{~d}$ & $86.69 \mathrm{c}$ & $76.52 \mathrm{c}$ & $1.31 \mathrm{~b}$ & $2.29 \mathrm{c}$ & $1.04 \mathrm{bc}$ \\
\hline $8 \% \mathrm{CO}_{2}-1 \% \mathrm{O}_{2}$ & $108.55 \mathrm{e}$ & $91.34 \mathrm{~d}$ & $78.38 \mathrm{~d}$ & $1.47 \mathrm{c}$ & $2.13 \mathrm{c}$ & $1.15 \mathrm{c}$ \\
\hline $10 \% \mathrm{CO}_{2}-3 \% \mathrm{O}_{2}$ & $88.80 \mathrm{~b}$ & $77.36 \mathrm{~b}$ & $52.28 \mathrm{~b}$ & $1.03 \mathrm{a}$ & $1.63 \mathrm{~b}$ & $0.94 \mathrm{~b}$ \\
\hline $15 \% \mathrm{CO}_{2}-3 \% \mathrm{O}_{2}$ & $85.76 \mathrm{a}$ & $63.38 \mathrm{a}$ & $28.66 \mathrm{a}$ & $1.00 \mathrm{a}$ & $1.39 \mathrm{a}$ & $0.69 \mathrm{a}$ \\
\hline
\end{tabular}

Note: see Table 1 
Fresh broccoli heads were found to have lower levels of indole-3carbinol as compared with sulforaphane content. In two years of the study, an increase in indole-3-carbinol was observed during storage. In the 2008/2009 and 2009/2010 storage seasons, the highest increase in indole3 -carbinol was observed in the atmospheres containing $5 \% \mathrm{CO}_{2}-3 \% \mathrm{O}_{2}$ and $8 \% \mathrm{CO}_{2}-1 \% \mathrm{O}_{2}$, while in the 2010/11 season, an increase in this component was recorded only in the atmosphere containing $15 \% \mathrm{CO}_{2}-3 \%$ $\mathrm{O}_{2}$. During storage, the level of sulforaphane increased, reaching the highest value in the atmosphere of 5\% $\mathrm{CO}_{2}-3 \% \mathrm{O}_{2}(2008 / 2009$ storage season), decreased (2009/2010 storage season), or remained at a level similar to that in fresh broccoli heads in all the treatments except the atmosphere of $8 \% \mathrm{CO}_{2}-1 \% \mathrm{O}_{2}$, in which there was an increase in the level of this component (2010/2011) (Table 5).

Table 5. Content of sulforaphane and indole-3-carbinol in fresh broccoli and after 100 days of storage

\begin{tabular}{lrrrrrr}
\hline & \multicolumn{3}{c}{$\begin{array}{c}\text { Sulforaphane } \\
\left(\mu \mathrm{g} \cdot \mathrm{g}^{-1} \mathrm{FW}\right)\end{array}$} & \multicolumn{3}{c}{$\begin{array}{c}\text { Indole-3-carbinol } \\
\left(\mu \mathrm{g}^{-1} \mathrm{FW}\right)\end{array}$} \\
\cline { 2 - 8 } \multicolumn{1}{c}{ Treatment } & \multicolumn{4}{c}{ Storage season } \\
\cline { 2 - 8 } & $\begin{array}{c}2008 / \\
2009\end{array}$ & $\begin{array}{c}2009 / \\
2010\end{array}$ & $\begin{array}{c}2010 / \\
2011\end{array}$ & $\begin{array}{c}2008 / \\
2009\end{array}$ & $\begin{array}{c}2009 / \\
2010\end{array}$ & $\begin{array}{c}2010 / \\
2011\end{array}$ \\
\hline $\begin{array}{l}\text { Fresh broccoli (before } \\
\text { storage) }\end{array}$ & $35.9 \mathrm{a}$ & $21.7 \mathrm{c}$ & $44.72 \mathrm{a}$ & $20.3 \mathrm{a}$ & $9.24 \mathrm{a}$ & $4.98 \mathrm{a}$ \\
\hline $5 \% \mathrm{CO}_{2}-3 \% \mathrm{O}_{2}$ & $82.8 \mathrm{e}$ & $15.6 \mathrm{~b}$ & $44.84 \mathrm{a}$ & $78.3 \mathrm{~d}$ & $31.2 \mathrm{~b}$ & $2.62 \mathrm{a}$ \\
\hline $8 \% \mathrm{CO}_{2}-1 \% \mathrm{O}_{2}$ & $38.5 \mathrm{c}$ & $12.3 \mathrm{~b}$ & $58.91 \mathrm{~b}$ & $43.5 \mathrm{c}$ & $36.5 \mathrm{~b}$ & $4.01 \mathrm{a}$ \\
\hline $10 \% \mathrm{CO}_{2}-3 \% \mathrm{O}_{2}$ & $37.2 \mathrm{~b}$ & $6.48 \mathrm{a}$ & $37.13 \mathrm{a}$ & $33.3 \mathrm{~b}$ & $17.5 \mathrm{a}$ & $4.51 \mathrm{a}$ \\
\hline $15 \% \mathrm{CO}_{2}-3 \% \mathrm{O}_{2}$ & $49.8 \mathrm{~d}$ & $20.8 \mathrm{c}$ & $42.75 \mathrm{a}$ & $28.0 \mathrm{~b}$ & $17.4 \mathrm{a}$ & $15.53 \mathrm{~b}$ \\
\hline
\end{tabular}

Note: see Table 1

According to the literature data, studies by other authors on storing broccoli in normal atmosphere involved storage periods from a few to 28 days. As reported by Winkler et al. (2007), the content of glucoraphanin the glycoside form of sulforaphane in fresh broccoli heads was 8.7 $\mu \mathrm{mol} \cdot \mathrm{g}^{-1} \mathrm{DW}$, whereas after $2,7,14$ and 28 days of storage in film packaging with perforations it ranged from 6.6 to $8.5 \mu \mathrm{mol} \cdot \mathrm{g}^{-1} \mathrm{DW}$ whether the broccoli heads were stored at $+1^{\circ} \mathrm{C}$ or $+4^{\circ} \mathrm{C}$. The authors found no significant differences in glucoraphanin content between the two storage temperatures or the storage periods even though the quality of the heads was significantly lower at the higher temperature and after longer periods of storage because of yellowing and the loss of turgor. Likewise, Rangkadilok et al. (2002) did not find any changes in glucoraphanin content in broccoli heads stored for 7 days at $+4^{\circ} \mathrm{C}$ whether in uncovered boxes or in plastic bags. Under such conditions the broccoli heads were green and looked as if freshly harvested. However, at $+20^{\circ} \mathrm{C}$ they observed a marked deterioration 
in the quality of the heads and a twofold decrease in glucoraphanin content compared with fresh heads. Hansen et al. (1995) recorded an increase in the total glucosinolate content in broccoli heads stored for 7 days at $+10^{\circ} \mathrm{C}$ from 47.1 to $67.0 \mu \mathrm{mol} \cdot \mathrm{g}^{-1} \mathrm{DW}$, and a slight decrease over the subsequent two days. The decrease in glucosinolates was accompanied by the yellowing of the heads. On the other hand, Rodrigues and Rosa (1999) recorded a reduction in glucoraphanin content by $31 \%$ after storing broccoli heads at $+4^{\circ} \mathrm{C}$ for 5 days, and a reduction of up to $82 \%$ in the level of this component after storage at $+20^{\circ} \mathrm{C}$. Chao-Jiong et al. (2006) recorded an increase in glucoraphanin content in broccoli heads during the first 6 days of storage: by $32 \%$ at $0^{\circ} \mathrm{C}$, $20 \%$ at $+5^{\circ} \mathrm{C}$, and just $2 \%$ at $+10^{\circ} \mathrm{C}$. Over the subsequent 6 days of storage there was a $2 \%$ decrease at $0^{\circ} \mathrm{C}, 23 \%$ at $+5^{\circ} \mathrm{C}$ (even though the broccoli heads were still of good quality), and a decrease of up to $60 \%$ at $+10^{\circ} \mathrm{C}$. At $+10^{\circ} \mathrm{C}$ there was a rapid loss of quality of broccoli heads.

The effect of controlled atmosphere on the quality and composition of broccoli heads in storage was studied, among others, by Hansen et al. (1995), who stored broccoli heads for 7 days at $+10^{\circ} \mathrm{C}$ in controlled atmospheres containing $0.5 \% \mathrm{O}_{2}, 0.5 \% \mathrm{O}_{2}+$ $20 \% \mathrm{CO}_{2}$, and with no oxygen in an atmosphere containing $20 \% \mathrm{CO}_{2}$. The authors found no changes in glucosinolate content in the atmosphere containing $0.5 \% \mathrm{O}_{2}$, compared with fresh broccoli heads, but showed a $21 \%$ increase in the atmosphere with $5 \% \mathrm{O}_{2}+20 \% \mathrm{CO}_{2}$, and a $15 \%$ decrease in the atmosphere containing
$20 \%$ carbon dioxide. The latter treatment produced visible signs of damage caused by carbon dioxide. Rangkadilok et al. (2002), while storing broccoli heads for 25 days at $+4^{\circ} \mathrm{C}$ in a controlled atmosphere containing $1.5 \% \mathrm{O}_{2}$ and $6 \% \mathrm{CO}_{2}$, and in normal atmosphere, found a higher glucoraphanin content in the heads stored in the controlled atmosphere than in those stored in the normal atmosphere. In a study by Chao-Jiong et al. (2006), broccoli heads were stored for 20 days at $+5^{\circ} \mathrm{C}$ in atmospheres containing $21 \% \mathrm{O}_{2}$ and $10 \% \mathrm{CO}_{2}, 21 \%$ $\mathrm{O}_{2}$ and $20 \% \mathrm{CO}_{2}, 21 \% \mathrm{O}_{2}, 1 \% \mathrm{O}_{2}$, and $1 \% \mathrm{O}_{2}$ and $10 \% \mathrm{CO}_{2}$. During the first 5 days of storage, the glucoraphanin content increased in the atmospheres of $21 \% \mathrm{O}_{2}+10 \% \mathrm{CO}_{2}$, $21 \% \mathrm{O}_{2}+20 \% \mathrm{CO}_{2}$ and in the atmosphere of $21 \%$ oxygen. An increase in glucoraphanin content was also observed in the normal atmosphere. The results obtained by those authors suggest that the increase in $\mathrm{CO}_{2}$ content induced the biosynthesis of glucoraphanin, and/or inactivated the enzyme myrosinase.

The results of the present authors' own research on the long-term storage of broccoli (up to 100 days) as well as the studies by other authors, outlined above, on the short-term storage (from a few to 28 days) indicate a complex mechanism of changes in the occurrence of glucosinolates in broccoli florets. There is no consistent trend in the effect of different gas compositions of controlled atmosphere on the glucosinolate content in stored broccoli heads. The difficulties in drawing firm conclusions arise from, among other things, the use by 
researchers of different storage parameters, for example, temperatures of $+4^{\circ} \mathrm{C},+5^{\circ} \mathrm{C},+10^{\circ} \mathrm{C}$, different gas compositions of the atmosphere, and different broccoli cultivars.

Table 6. Colour indices of broccoli heads after 100 days of storage in CA

\begin{tabular}{cccrrrr}
\hline $\begin{array}{c}\text { Storage } \\
\text { season }\end{array}$ & $\begin{array}{c}\text { Colour } \\
\text { index }\end{array}$ & $\begin{array}{c}\text { Fresh } \\
\text { broccoli }\end{array}$ & \multicolumn{1}{c}{$\begin{array}{c}5 \% \mathrm{CO}_{2}- \\
3 \% \mathrm{O}_{2}\end{array}$} & \multicolumn{1}{c}{$\begin{array}{c}8 \% \mathrm{CO}_{2}- \\
1 \% \mathrm{O}_{2}\end{array}$} & \multicolumn{1}{c}{$10 \% \mathrm{CO}_{2}-$} & \multicolumn{1}{c}{$\begin{array}{c}15 \% \mathrm{CO}_{2}- \\
3 \% \mathrm{O}_{2}\end{array}$} \\
\hline \multirow{2}{*}{$2008 /$} & $\mathrm{L} \pm \mathrm{sd}$ & $31.82 \pm 1.69$ & $33.49 \pm 1.57$ & $31.75 \pm 2.29$ & $31.44 \pm 1.57$ & $31.09 \pm 1.99$ \\
2009 & $\mathrm{a} \pm \mathrm{sd}$ & $-4.33 \pm 0.96$ & $-4.50 \pm 0.33$ & $-4.48 \pm 0.38$ & $-4.65 \pm 0.31$ & $-4.64 \pm 0.37$ \\
& $\mathrm{~b} \pm \mathrm{sd}$ & $7.88 \pm 1.33$ & $9.79 \pm 0.74$ & $9.17 \pm 0.98$ & $9.09 \pm 0.84$ & $9.56 \pm 0.90$ \\
\hline \multirow{2}{*}{$2009 /$} & $\mathrm{L} \pm \mathrm{sd}$ & $36.75 \pm 1.37$ & $34.47 \pm 177$ & $35.37 \pm 2.23$ & $34.74 \pm 1.37$ & $34.42 \pm 1.78$ \\
2010 & $\mathrm{a} \pm \mathrm{sd}$ & $-7.14 \pm 0.58$ & $-5.73 \pm 0.51$ & $-5.45 \pm 0.42$ & $-5.6 \pm 0.38$ & $-5.93 \pm 0.39$ \\
& $\mathrm{~b} \pm \mathrm{sd}$ & $13.49 \pm 1.26$ & $13.86 \pm 1.58$ & $14.28 \pm 2.23$ & $14.15 \pm 1.49$ & $14.86 \pm 1.29$ \\
\hline \multirow{2}{*}{$2010 /$} & $\mathrm{L} \pm \mathrm{sd}$ & $38.82 \pm 1.00$ & $40.43 \pm 1.14$ & $39.53 \pm 1.59$ & $35.59 \pm 2.66$ & $35.02 \pm 3.71$ \\
2011 & $\mathrm{a} \pm \mathrm{sd}$ & $-7.95 \pm 0.96$ & $-5.9 \pm 0.25$ & $-6.28 \pm 0.3$ & $-7.00 \pm 0.36$ & $-6.38 \pm 0.44$ \\
& $\mathrm{~b} \pm \mathrm{sd}$ & $16.7 \pm 1.32$ & $16.33 \pm 0.98$ & $15.45 \pm 1.18$ & $14.98 \pm 0.88$ & $13.34 \pm 1.01$ \\
\hline
\end{tabular}

L - lightness, a - greenness, b - yellowness, SD - standard deviation

\section{CONCLUSIONS}

1. Broccoli heads kept for 100 days in controlled atmosphere maintained a satisfactory to quite good marketable value, whereas those stored in normal atmosphere almost completely lost their marketable value because of extensive decay.

2. The total content of sulforaphane and indole-3-carbinol in fresh broccoli heads was lower compared with stored broccoli heads. The most favourable effect on the glucosinolate content was that of storing broccoli heads in an atmosphere containing 5\% carbon dioxide and $3 \%$ oxygen.

3. Storing broccoli heads in controlled atmosphere resulted in significant losses in ascorbic acid and sugars. The highest losses of these components occurred in those broccoli heads that were stored in an atmosphere containing 15\% carbon dioxide and $3 \%$ oxygen.

4. In two storage seasons, the different gas compositions of controlled atmosphere had no effect on the colour of broccoli heads.

\section{REFERENCES}

Adamicki F., Czerko Z. 2002. Przechowalnictwo warzyw i ziemniaka. PWRiL: pp. 324. [in Polish]

Aires A., Rosa E., Carvalho R. 2006. Effect of nitrogen and sulfur fertilization on glucosinolates in the leaves and roots of broccoli sprouts (Brassica oleracea var. italica). Journal of the Science of Food and Agriculture. 86 (10): 1512-1516.

Bellostas N., Kachlicki P., Sørensen J.C., Sørensen H. 2007. Glucosinolate profiling of seeds and sprouts of $B$. oleracea varieties used for food. Scienta Horticulturae 114: 234-242. 
Bradlow H.L., Sepkovic D.W., Telang N.T., Osborne M.P. 1999. Multifunctional aspects of the action of indole-3-carbinol as an antitumor agent. Ann. NY Acad. Sci. 889: 204-213.

Brown P.D., Tokuhisa J.G., Reichelt M., Gershenzon J. 2003. Variation of glucosinolate accumulation among different organs and developmental stages of Arabidopsis thaliana. Phytochemistry 62: 471-481.

Cartea M.E., Velasco P., Obregon S., Padilla G., de Haro A. 2008. Seasonal variation in glucosinolate content in Brassica oleracea crops grown in northwestern Spain. Phytochemistry 69: 403-410.

Chao-Jiong X., De-Ping G., Jing Y., GaoFeng Y., Qiao-Mei W. 2006. Changes in glucoraphanin content and quinone reductase activity in broccoli (Brassica oleracea var. italica) florets during cooling and controlled atmosphere storage. Posharvest Biology and Technology 42: 176-184.

Charron C.S., Saxton A.M., Sams C.E. 2005. Relationship of climate and genotype to seasonal variation in the glucosinolate myrosinase system. I. Glucosinolate content in ten cultivars of Brassica oleracea grown in fall and spring seasons. Journal of the Science of Food and Agriculture 85(4): 671-681.

Ciska E., Martyniak-Przybyszewska B., Kozłowska H. 2000. Content of glucosinolates in Cruciferous vegetables grown at the same site for two years under different climatic conditions. J. Agric. Food Chem. 48: 2862-2867.

Fahey J.W., Zhang Y., Talalay P. 1997. Broccoli sprouts: an exceptionally rich source of inducers of enzymes that protect against chemical carcin- ogens. Proc. Natl. Acad. Sci. USA. vol. 94, no 19: 10367-10372.

Fahey J.W., Talalay P. 1999. Antioxidant functions of sulforaphane: a potent inducer of phase II detoxication enzymes. Food and Chemical Toxicology. 37: 973-979.

Fahey J.W., Stephenson K.K. 1999. Cancer chemoprotective effects of cruciferous vegetables. HortScience, vol. 34(7): 1159-1163.

Farnham M.W., Stephenson K.K., Fahey J.W. 2005. Glucoraphanin level in broccoli seed is largely determined by genotype. HortScience 40(1): 50-53.

Farnham M.W., Wilson P.E., Stephenson K.K., Fahey J.W. 2004. Genetic and environmental effects on glucosinolate content and chemoprotective potency of broccoli. Plant Breeding 123: 60-65.

Gajewski M., Przybył J.L., Bajer M., Jariene E. 2011. The influence of controlled atmosphere storage on phytosterols in broccoli heads. Journal of Food Processing and Preservation 35: 722-728.

Hansen M., Møller P., Sørensen H., Cantwell de Trejo M. 1995. Glucosinolates in broccoli stored under controlled atmosphere. J. Amer. Soc. Hort. Sci. 120(6): 1069-1074.

Horbowicz M., Babik I. 2005a. Sulphoraphane and flavonoid contents in chosen broccoli cultivars. Veget. Crops Res. Bull. 62: 127-137.

Horbowicz M., Babik I. 2005b. Effect of potassium sulfate fertilization on content of some bioactive constituents in broccoli cv. Marathon $\mathrm{F}_{1}$. Veget. Crops Res. Bull. 63: 109-116.

Jones R.B., Faragher J.D., Winkler S. 2006. A review of the influence of postharvest treatments on quality and glucosinolate content in broccoli (Brassica oleracea var. italica) heads. Postharvest Biology and Technology 41: 1-8. 
Jones R.B., Imsic M., Franz P., Hale G., Tomkins R.B. 2007. High nitrogen during growth reduced glucoraphanin and flavonol content in broccoli (Brassica oleracea var. italica) heads. Australian Journal of Experimental Agriculture 47 (12): 1498-1505.

Jagdish S., Mathura R., Upadhyay A.K., Kundan P. 2007. Sinigrin (2propenyl glucosinolate) content and myrosinase activity in Brassica vegetables. International Journal of Vegetable Science 13(2): 21-31.

Kushad M.M., Brown A.F., Kurilich A.C., Juvik J.A., Klein B.P., Wallig M.A., Jeffery E.H. 1999. Variation of glucosinolates in vegetable crops of Brassica oleracea. J. Agric. Food Chem. 47: 1541-1548.

Liang H., Yuan Q.P., Dong H.R., Liu Y.M. 2006. Determination of sulforaphane in broccoli and cabbage by high-performance liquid chromatography. Journal of Food Composition and Analysis. 19 (5): 473-476.

Liang H., Li Ch., Yuan Q., Vriesekoop F. 2007. Separation and purification of sulforaphane from broccoli seeds by solid phase extraction and preparative high-performance liquid chromatography. J. Agric. and Food Chem. 55: 8047-8053.

O’Hare T.J., Wong L.S., Force L.E. 2007. Glucosinolate composition and anticancer potential of seed-sprouts from horticultural members of the Brassicaceae. Proc. $1^{\text {st }}$ IS on Hum. Health Effects of F\&V. ISHS, Acta Hort. 744: 181-188.

Rangkadilok N., Tomkins B., Nicolas M.E., Premier R.R., Bennett R..N., Eagling D.R., Taylor P.W.J. 2002. The effect of post-harvest and packaging treatments on glucoraphanin concentration in broccoli (Brassica oleracea var. italica). J. Agric. Food Chem. 50: 7386-7391.

Rodrigues A.S., Rosa E.A.S. 1999. Effect of post-harvest treatments on the level of glucosinolates in broccoli. J. Sci. Food Agric. 79: 1028-1032

Rosa E.A.S., Rodrigues A.S. 2001. Total and individual glucosinolate content in 11 broccoli cultivars grown in early and late seasons. HortScience 36(1): 56-59.

Rosa E., Pereira F.M.V., Aires A.A., Carvalho R. 2007. Effects of postharvest storage conditions on the levels of glucosinolates in broccoli sprouts (Brassica oleracea var. italica) grown under different temperature regimes. Journal of Horticultural Science \& Biotechnology 82 (6): 974-978.

Sosińska E., Obiedziński M.W. 2007. [Investigation on bioactive glucosinolates in chosen cruciferous vegetables varieties by HPLC.] Żywność Nauka Technologia Jakość 5 (54): 129-136. [in Polish with English summary]

Schonhof I., Kläring H.P., Krumbein A., Schreiner M. 2007. Interaction between atmospheric $\mathrm{CO}_{2}$ and glucosinolates in broccoli. J. Chem. Ecol 33: 105-114.

Schouten R.E., Zhang X., Verschoor J.A., Otyma Els.C., Tijskens L.M.M., Kooten O. 2009. Development of colour of broccoli heads as affected by controlled atmosphere storage and temperature. Posharvest Biology and Technology 51: 27-35.

Winkler S., Faragher J., Franz P., Imsic M., Jones R. 2007. Glucoraphanin and flavonoid levels remain stable during simulated transport and marketing of broccoli (Brassica oleracea var. italica) heads. Posharvest Biology and Technology 43(1): 89-94.

Van Poppel G., Verhoeven D.T., Verhagen H., Goldbohm R.A. 1999. 
Brassica vegetables and cancer prevention. Epidemiology and mechanisms. Adv. Exp. Med. Biol. 472: 159-168.

Zhang Y., Talalay P., Cho Ch-Gy., Posner

G.H. 1992. A major inducer of anticarcinogenic protective enzymes from broccoli: isolation and elucidation of structure. Proc. Natl. Acad. Sci. USA. Medicinal Sciences 89: 2399-2403.

\section{WPŁYW PRZECHOWYWANIA W KONTROLOWANEJ ATMOSFERZE NA JAKOŚĆ I ZAWARTOŚĆ ZWIAZZKÓW PROZDROWOTNYCH W BROKULE}

\section{Streszczenie}

Celem badań prowadzonych w latach 2008-2011 było określenie wpływu warunków przechowywania na jakość róż brokułu i zawartość w nich związków prozdrowotnych. Brokuły odm. Marathon $\mathrm{F}_{1}$ były przechowywane $100 \mathrm{dni}$ w temperaturze $0^{\circ} \mathrm{C}$, w kontrolowanej atmosferze zawierającej: 1) $15 \% \mathrm{CO}_{2}-3 \% \mathrm{O}_{2}$, 2) $10 \% \mathrm{CO}_{2}-3 \% \mathrm{O}_{2}$, 3) $8 \% \mathrm{CO}_{2}-1 \% \mathrm{O}_{2}$, 4) $5 \% \mathrm{CO}_{2}-3 \% \mathrm{O}_{2}$ oraz w atmosferze normalnej w skrzynkach wyłożonych folią polietylenową (kontrola). Bezpośrednio po zbiorze oraz po przechowaniu wykonano analizy chemiczne na zawartość witaminy $\mathrm{C}$, cukrów ogółem oraz glukozynolanów - sulforafanu i indolilo-3-karbinolu. Po przechowaniu oceniono wizualnie jakość róż w skali 10 -stopniowej. Określono również procentowy udział róż handlowych po przechowaniu oraz barwę.

Sumaryczna zawartość sulforafanu i indolilo-3-karbinolu w brokułach świeżych była niższa $\mathrm{w}$ porównaniu $\mathrm{z}$ brokułami przechowywanymi. Zawartość sulforafanu w różach świeżych była około 2-krotnie wyższa w porównaniu z zawartością indolilo-3karbinolu. Przechowywanie w kontrolowanej atmosferze zawierającej 5\% $\mathrm{CO}_{2}-3 \% \mathrm{O}_{2}$, wpływało korzystniej na zawartość glukozynolanów w porównaniu z innymi obiektami. Najwyższą zawartość witaminy $\mathrm{C}$ i cukrów ogółem notowano w różach świeżych. W czasie przechowywania nastąpił spadek zawartości składników we wszystkich obiektach. Najwyższe straty tych składników wystapiły w różach przechowywanych w atmosferze zawierającej $15 \% \mathrm{CO}_{2}-3 \% \mathrm{O}_{2}$. Brokuły przechowywane w normalnej atmosferze całkowicie utraciły wartość handlową z powodu gnicia, żółknięcia i utraty zwartości. Brokuły przechowywane w pozostałych koncentracjach tlenu i dwutlenku węgla zachowały zadowalającą wartość handlową. 